\title{
Understanding in situ ozone production in the summertime through rad- ical observations and modelling studies during the Clean air for London project (ClearfLo)
}

Lisa K. Whalley et al.

Correspondence to: Lisa K. Whalley (1.k.whalley@leeds.ac.uk) and Dwayne E. Heard (d.e.heard@leeds.ac.uk)

The copyright of individual parts of the supplement might differ from the CC BY 4.0 License. 


\section{Supplementary Information}

\section{Estimating the contribution of $\mathrm{CH}_{3} \mathrm{O}_{2} \mathrm{NO}_{2}$ to the $\mathrm{RO}_{2}$ signal}

In the main paper we do not apply a correction for a possible contribution of methyl peroxy nitric acid $\left(\mathrm{CH}_{3} \mathrm{O}_{2} \mathrm{NO}_{2}\right)$ to the $\mathrm{RO}_{2}$ measurement (Fuchs et al., 2008). Here, however, we explore the implications of a $\mathrm{CH}_{3} \mathrm{O}_{2} \mathrm{NO}_{2}$ interference on the reported $\mathrm{RO}_{2}$ levels. First we make some definitions. We refer to the measurement of non-interfering $\mathrm{RO}_{2}$ species $\left(\mathrm{RO}_{2} n i\right)$ which could include a contribution from the thermal decomposition of $\mathrm{CH}_{3} \mathrm{O}_{2} \mathrm{NO}_{2}$ as $\mathrm{RO}_{2} n i^{*}$ :

$\left[\mathrm{RO}_{2} n i^{*}\right]=\left[\mathrm{RO}_{2}\right.$ tot. $]-\left[\mathrm{RO}_{2} i\right]-\left[\mathrm{HO}_{2}\right]$

If the concentration of the non-interfering $\mathrm{RO}_{2}\left(\mathrm{RO}_{2}\right.$ ni) is dominated by $\mathrm{CH}_{3} \mathrm{O}_{2}$, i.e. $\left[\mathrm{RO}_{2}\right.$ ni] $\approx\left[\mathrm{CH}_{3} \mathrm{O}_{2}\right]$, it becomes possible to estimate the ambient concentration of $\mathrm{CH}_{3} \mathrm{O}_{2} \mathrm{NO}_{2}$ using equilibrium rate constant $\left(\mathrm{K}_{\mathrm{eq}}=3.6 \times 10^{-12} \mathrm{~cm}^{3}\right.$ at $\left.298 \mathrm{~K} ; \mathrm{MCMv3.2}\right)$, the uncorrected $\mathrm{RO}_{2}$ radical measurements, $\left[\mathrm{RO}_{2} n i^{*}\right]$, and $\left[\mathrm{NO}_{2}\right]$ :

$\left[\mathrm{RO}_{2} n i^{*}\right] \approx\left[\mathrm{CH}_{3} \mathrm{O}_{2}\right]+\left[\mathrm{CH}_{3} \mathrm{O}_{2} \mathrm{NO}_{2}\right]$

$\left[\mathrm{CH}_{3} \mathrm{O}_{2} \mathrm{NO}_{2}\right]=\mathrm{K}_{\mathrm{eq}}\left[\mathrm{CH}_{3} \mathrm{O}_{2}\right]\left[\mathrm{NO}_{2}\right]$

rearranging (2) and (3):

$\left[\mathrm{CH}_{3} \mathrm{O}_{2}\right]=\left[\mathrm{RO}_{2} n i^{*}\right]-\left[\mathrm{CH}_{3} \mathrm{O}_{2} \mathrm{NO}_{2}\right]$

$\left[\mathrm{CH}_{3} \mathrm{O}_{2}\right]=\frac{\left[\mathrm{CH}_{3} \mathrm{O}_{2} \mathrm{NO}_{2}\right]}{\mathrm{K}_{\mathrm{eq}}\left[\mathrm{NO}_{2}\right]}$

combining (4) and (5):

$\left[\mathrm{RO}_{2} n i^{*}\right]-\left[\mathrm{CH}_{3} \mathrm{O}_{2} \mathrm{NO}_{2}\right]=\frac{\left[\mathrm{CH}_{3} \mathrm{O}_{2} \mathrm{NO}_{2}\right]}{\mathrm{K}_{\mathrm{eq}}\left[\mathrm{NO}_{2}\right]}$

$\left[\mathrm{RO}_{2} n i^{*}\right]=\left[\mathrm{CH}_{3} \mathrm{O}_{2} \mathrm{NO}_{2}\right]+\frac{\left[\mathrm{CH}_{3} \mathrm{O}_{2} \mathrm{NO}_{2}\right]}{\mathrm{K}_{\mathrm{eq}}\left[\mathrm{NO}_{2}\right]}$

$\left[\mathrm{RO}_{2} n i^{*}\right]=\left[\mathrm{CH}_{3} \mathrm{O}_{2} \mathrm{NO}_{2}\right]\left(1+1 / \mathrm{K}_{\mathrm{eq}}\left[\mathrm{NO}_{2}\right]\right)$

$\left[\mathrm{CH}_{3} \mathrm{O}_{2} \mathrm{NO}_{2}\right]=\frac{\left[\mathrm{RO}_{2} n i^{*}\right]}{\left(1+1 / \mathrm{K}_{\mathrm{eq}}\left[\mathrm{NO}_{2}\right]\right.}$

Subtracting the determined methyl peroxy nitric acid concentration from $\left[n i \mathrm{RO}_{2}{ }^{*}\right]$ offers a correction for this artefact:

$\left[\mathrm{RO}_{2} n i\right]=\left[\mathrm{RO}_{2} n i^{*}\right]-\left[\mathrm{CH}_{3} \mathrm{O}_{2} \mathrm{NO}_{2}\right]$

In the following figures, both the corrected (brown) and non-corrected (dark-green) $\mathrm{RO}_{2}$ measurements are presented for comparison, where:

$\left[\mathrm{RO}_{2}\right]_{\mathrm{CORR}}=\left[\mathrm{RO}_{2} n i\right]+\left[\mathrm{RO}_{2} i\right]$

$\left[\mathrm{RO}_{2}\right]_{\mathrm{NON}-\mathrm{CORR}}=\left[\mathrm{RO}_{2} n i^{*}\right]+\left[\mathrm{RO}_{2} i\right]$ 

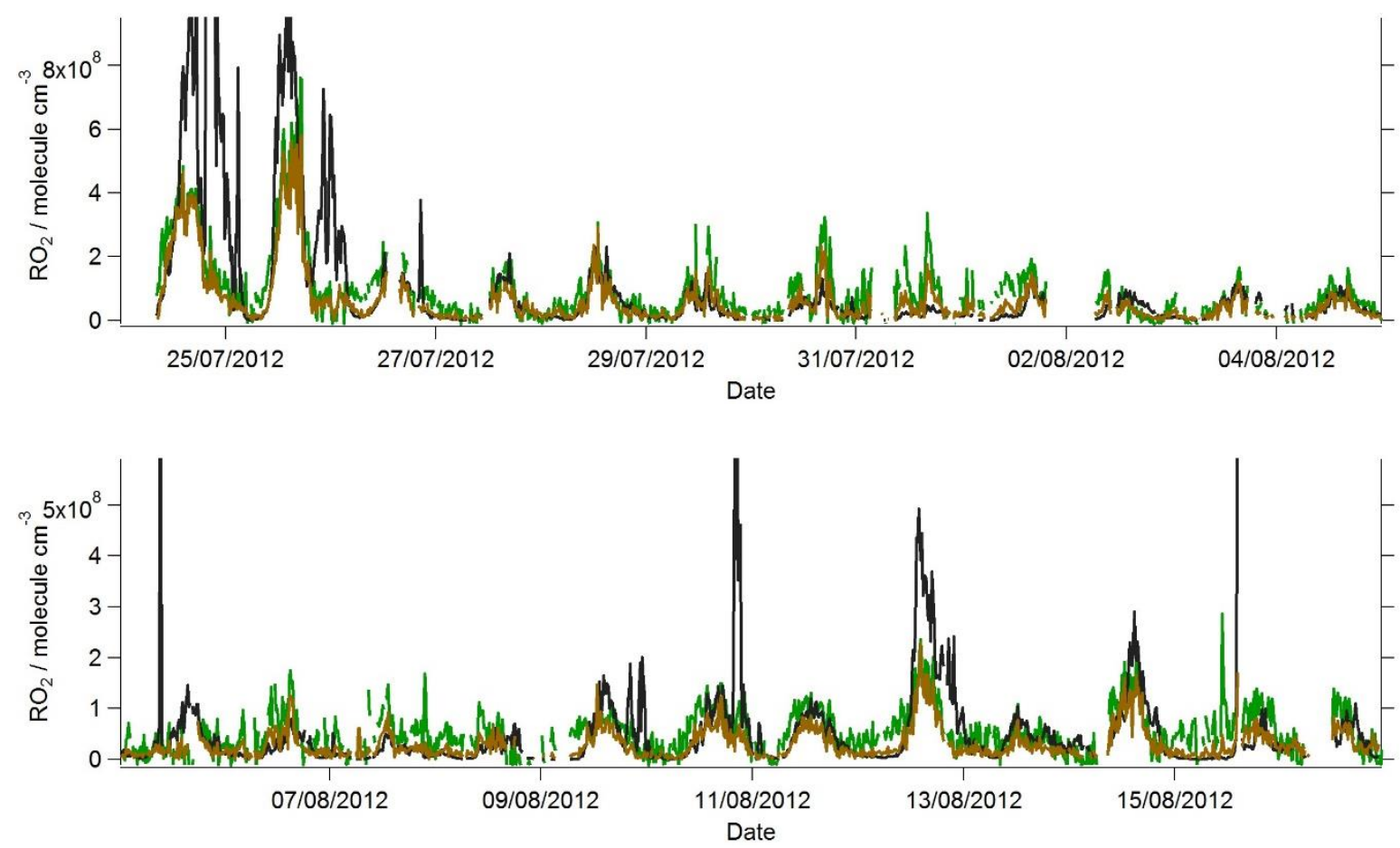

Figure S1: Observed (coloured lines) and MCM-BASE modelled (black lines) $\mathrm{RO}_{2}$ during the summer ClearfLo IOP. Brown = $\left[\mathrm{RO}_{2}\right]_{\text {CORR }}\left(\right.$ see Eqn.11) and dark-green $=\left[\mathrm{RO}_{2}\right]_{\mathrm{NON}-\mathrm{CORR}}($ see Eqn.12). Data time resolution of each data point is 15 minutes.
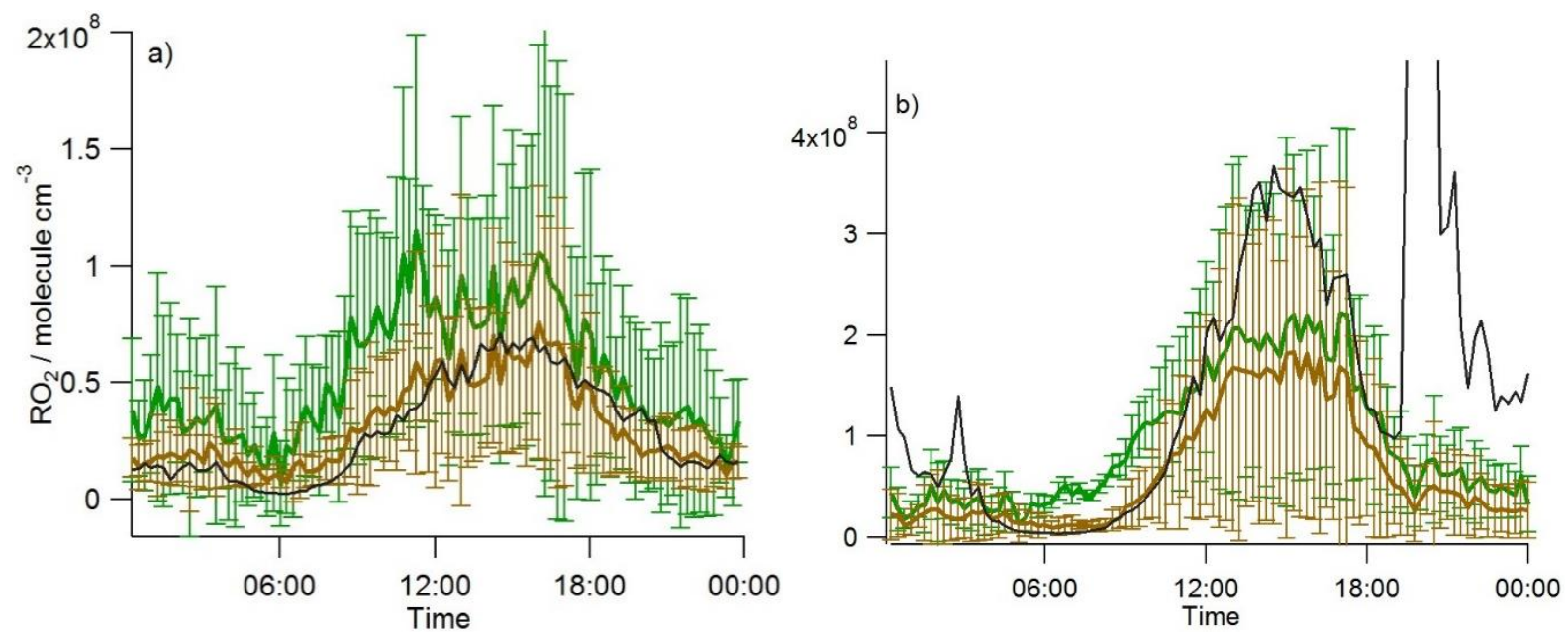

Figure S2: Average diel observed (colour) and MCM-BASE (black) $\mathrm{RO}_{2}$ profiles during a) south-westerly and b) easterly flows. Brown $=\left[\mathrm{RO}_{2}\right]_{\text {CORR }}\left(\right.$ see Eqn.11) and dark-green $=\left[\mathrm{RO}_{2}\right]_{\text {NON-CORR }}($ see Eqn.12) 


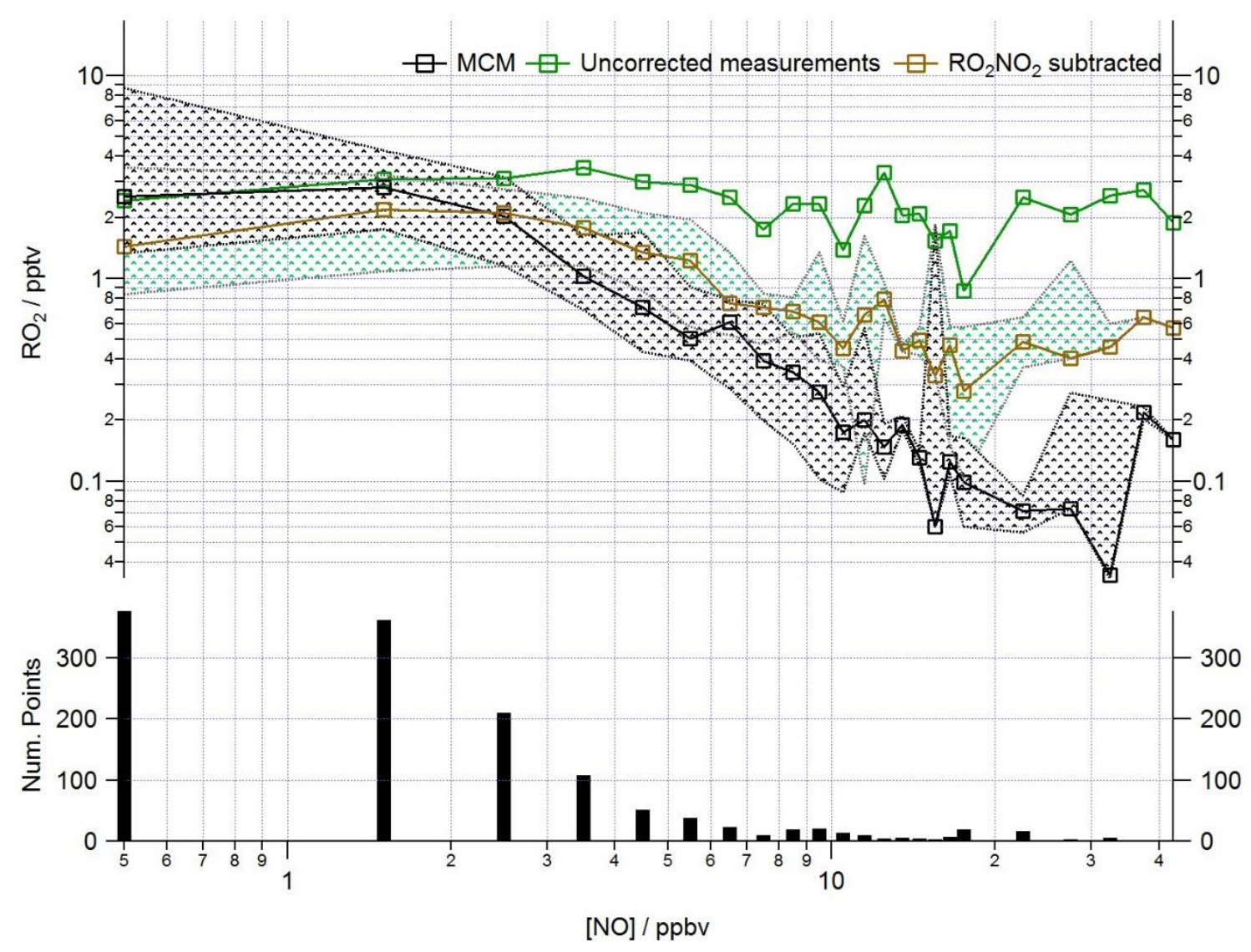

Figure S3: Median $\mathrm{RO}_{2}$ measured (dark green squares = no correction for $\mathrm{CH}_{3} \mathrm{O}_{2} \mathrm{NO}_{2}$ decomposition applied, brown squares = $\mathrm{RO}$ with the possible contribution from $\mathrm{CH}_{3} \mathrm{O}_{2} \mathrm{NO}_{2}$ decomposition subtracted) and $\mathrm{RO}_{2}$ modelled (black squares); $25 / 75^{\text {th }}$ percentiles represented by patterned areas. Data are filtered for daytime hours between 6 am and 7 pm and binned by [NO] with a bin width = 1 ppbv for [NO] between $0-20$ ppbv and bin width = 5 ppbv for [NO] between $20-45$ ppbv. The number of points in each bin is displayed in the lower panel.

\section{Testing the sensitivity of the model to different model parameters}

\subsection{Deviation from a NOx photo-stationary steady state (PSS)}

In this central urban location, local sources of pollution, for example emissions from nearby roads, likely influenced the radical concentrations observed. The very busy Ladbroke Grove road was approximately $75 \mathrm{~m}$ from the ClearfLo site and so at windspeeds greater than $1.25 \mathrm{~ms}^{-1}$, air passing over this road would reach the site within 1 minute. Following an injection of NO from a local traffic source, it can take up to minute for $\mathrm{NO}_{\mathrm{x}}$ to reach PSS (Brune et al., 2016). It is likely, therefore, that $\mathrm{NO}_{\mathrm{x}}$ levels will have varied rapidly in time in air from the direction of Ladbroke Grove prior to reaching the ClearfLo site. In this 
work, the model methodology involved running each model point to steady state conditions, i.e., for a sufficient time that the concentration of the radicals did not change for a set of model inputs. The concentration/value of the model inputs for each model time point was held constant and assumed not to vary over the time it took for the radical levels to reach steady state. At high $\mathrm{NO}$ concentrations, the lifetime of $\mathrm{HO}_{2}$ radicals is short (e.g. $\tau_{\mathrm{HO}_{2}}=\frac{1}{k_{\mathrm{HO}_{2}+\mathrm{NO}[\mathrm{NO}]}}$ is $<1 \mathrm{~s}$ at an $[\mathrm{NO}]=10 \mathrm{ppbv}$ ) and so under these conditions this modelling approach is likely valid. When the lifetime of $\mathrm{HO}_{2}$ is longer ( $\tau_{\mathrm{HO}_{2}}$ is $\sim 45 \mathrm{sec}$ at [NO] $=100$ pptv), however, the time taken for radicals to reach PSS increases and the assumption that the modelled inputs (particularly $\mathrm{NO}_{\mathrm{x}}$ concentrations) do not vary over the e-folding lifetime of $\mathrm{HO}_{2}$ no longer holds. As discussed in section 3.3.1, the model is unable to capture the observed levels of $\mathrm{HO}_{2}$ under low $\mathrm{NO}_{\mathrm{x}}$ conditions, i.e. when the lifetime of $\mathrm{HO}_{2}$ is long, and this may, in part, relate to the way the model was run. We might expect a model to predict a lower $\left[\mathrm{HO}_{2}\right]$ for an air-mass that had been transported from a region of higher [NO] and the integral [NO] over the lifetime of $\mathrm{HO}_{2}$ was used rather than the [NO] observed at the end. To assess the influence of upwind emissions (and $\mathrm{NO}_{\mathrm{x}}$ being out of PSS), an additional constant local $\mathrm{NO}$ source $=4 \mathrm{ppb}$ has been inputted into the model (MCM-NO) and this helps to bring the modelled $\mathrm{HO}_{2}$ into agreement with the measurements (brown line, Fig. S4). However, the model further over-predicts $\mathrm{OH}$ concentrations and under-predicts $\mathrm{RO}_{2}$ by close to a factor of two in this scenario (see Fig. S4), indicating that deviations from $\mathrm{NO}_{\mathrm{x}} \mathrm{PSS}$ over the lifetime of $\mathrm{HO}_{2}$ alone cannot reconcile the discrepancies between the model and observations for all of the radicals.

\subsection{Missing $\mathrm{HO}_{2}$ radical sink}

Including a first order loss process for $\mathrm{HO}_{2}$ equal to $0.3 \mathrm{~s}^{-1}$ in the model (MCM- $k_{\text {loss } 0.3}$ ) improves the model measurement agreement during the daytime for $\mathrm{HO}_{2}$ considerably (grey, solid line, Fig. $\mathrm{S} 4, \mathrm{HO}_{2}$ panel only). The impact on local ozone production if this sink is overlooked in a model is explored in section 4.2 (main manuscript). Although in general the modelto-measured agreement for the peroxy radicals improves when a large first order loss process for $\mathrm{HO}_{2}$ is included, under south

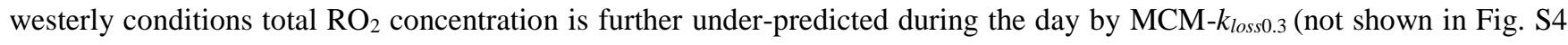
for clarity, but has very similar profile to $\mathrm{MCM}-\mathrm{HO}_{2}$ ). The model has a tendency to under-predict $\mathrm{OH}$ reactivity (Whalley et al., 2016) during the day under the south westerly flows (by up to $25 \%$ ) even when an extended VOC suite and the model intermediate contribution to $\mathrm{OH}$ reactivity is considered. This suggests that the model may be missing VOCs under this airmass regime and this, in turn may contribute to the model under-prediction of $\mathrm{RO}_{2}$.

With the inclusion of this large $\mathrm{HO}_{2}$ sink, $[\mathrm{OH}]_{\mathrm{MCM} \_ \text {kloss } 0.3}$ closely resembles $\mathrm{OH}_{\mathrm{PSS}}$ and the observed $\mathrm{OH}$ is under-predicted slightly during the afternoon during the first easterly air-mass encountered.

\subsection{Under-estimating the heterogeneous $\mathrm{HO}_{2}$ sink}

Uptake probabilities of less than $\gamma \mathrm{HO}_{2}=0.02$ to sub-micron aerosols at room temperature have been reported (George et al., 2013) for inorganic salts. Enhanced uptakes (up to $\gamma \mathrm{HO}_{2}=0.5$ ), however, have been reported on aerosols containing $\mathrm{Cu}$ or $\mathrm{Fe}$ ions (Mozurkewich et al., 1987; Lakey et al., 2016). Changes in physical parameters such as temperature or pH have also been 
shown in laboratory studies (Lakey, 2014) and in the field (Whalley et al., 2015) to change the value of $\gamma \mathrm{HO}_{2}$. Combustion processes are considered important sources of $\mathrm{Cu}$-containing sub-micron aerosols (Mao et al., 2013) and so in an urban environment, characterised by high vehicular emissions, some enhancements in the uptake coefficient may be expected due to the presence of these ions within the aerosols. In the base model discussed thus far, an uptake probability of 0.1 was assumed to reflect possible enhancements. Other modelling studies have considered a range of $\mathrm{HO}_{2}$ uptake probabilities in attempt to resolve model over-predictions e.g. (Emmerson et al., 2007). Figure S4, (grey dashed line) shows the maximum possible impact of this $\mathrm{HO}_{2}$ sink term by increasing the uptake probability from 0.1 to 1 . This enhancement only reduces the modelled $\mathrm{HO}_{2}$ concentration modestly, with improvements most significant during the easterly flows when aerosol surface area was most elevated. Despite these reductions, significant over-predictions remain, demonstrating that heterogeneous loss to aerosol surfaces alone cannot resolve the model measurement discrepancy.
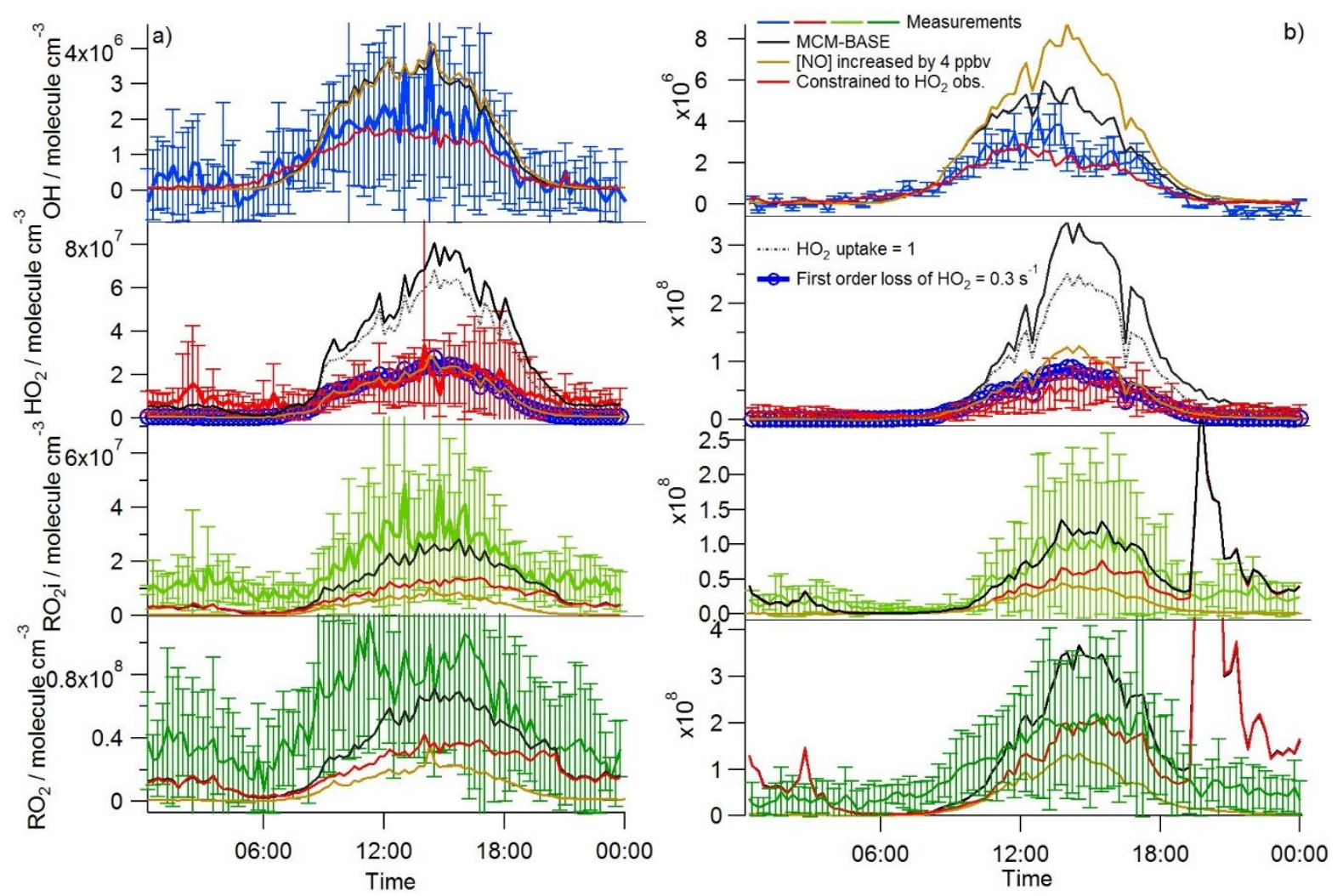

Figure S4: Average diel observed and modelled $\mathrm{HO}_{\mathrm{x}}$ profiles during a) south-westerly and b) easterly flows. The MCM base model predictions are shown in black. The model scenario (MCM-NO) where the modelled NO concentration was increased by 4 ppbv is shown in brown. The red line is the model scenario constrained to the observed $\mathrm{HO}_{2}\left(\mathrm{MCM}_{-} \mathrm{HO}_{2}\right)$. $\mathrm{HO}_{2}$ panel only: The grey dashed line is the model scenario where an $\mathrm{HO}_{2}$ uptake coefficient to aerosol $=1$ was included $\left(\mathrm{MCM}-\gamma \mathrm{HO}_{2}\right)$ and blue open circles represents the model scenario where a constant first order loss of $\mathrm{HO}_{2}$ equal to $0.3 \mathrm{~s}^{-1}$ is included (MCM- $k_{\text {losso.3) }}$. 


\section{References}

Brune, W. H., Baier, B. C., Thomas, J., Ren, X., Cohen, R. C., Pusede, S. E., Browne, E. C., Goldstein, A. H., Gentner, D. R., Keutsch, F. N., Thornton, J. A., Harrold, S., Lopez-Hilfiker, F. D., and Wennberg, P. O.: Ozone production chemistry in the presence of urban plumes, Faraday Discuss, 189, 169-189, 10.1039/c5fd00204d, 2016.

Emmerson, K. M., Carslaw, N., Carslaw, D. C., Lee, J. D., McFiggans, G., Bloss, W. J., Gravestock, T., Heard, D. E., Hopkins, J., Ingham, T., Pilling, M. J., Smith, S. C., Jacob, M., and Monks, P. S.: Free radical modelling studies during the UK TORCH Campaign in Summer 2003, Atmos Chem Phys, 7, 167-181, 2007.

Fuchs, H., Holland, F., and Hofzumahaus, A.: Measurement of tropospheric RO2 and HO2 radicals by a laser-induced fluorescence instrument, Rev Sci Instrum, 79, Artn 084104

10.1063/1.2968712, 2008 .

George, I. J., Matthews, P. S. J., Whalley, L. K., Brooks, B., Goddard, A., Romero, M. T. B., and Heard, D. E.: Measurements of uptake coefficients for heterogeneous loss of $\mathrm{HO}_{2}$ onto submicron inorganic salt aerosols, Physical Chemistry Chemical Physics, 15, 12859-12845, 2013.

Lakey, P. S. J.: Heterogeneous uptake of $\mathrm{HO} 2$ radicals onto atmospheric aerosols, PhD, School of Chemistry, University of Leeds, Leeds, 2014.

Lakey, P. S. J., George, I. J., Baeza-Romero, M. T., Whalley, L. K., and Heard, D. E.: Organics Substantially Reduce HO2 Uptake onto Aerosols Containing Transition Metal ions, J Phys Chem A, 120, 1421-1430, 10.1021/acs.jpca.5b06316, 2016.

Mao, J., Fan, S., Jacob, D. J., and Travis, K. R.: Radical loss in the atmosphere from Cu-Fe redox coupling in aerosols, Atmos Chem Phys, 13, 509-519, 10.5194/acp-13-509-2013, 2013.

Mozurkewich, M., Mcmurry, P. H., Gupta, A., and Calvert, J. G.: Mass Accommodation Coefficient for Ho2 Radicals on Aqueous Particles, J Geophys Res-Atmos, 92, 4163-4170, Doi 10.1029/Jd092id04p04163, 1987.

Whalley, L. K., Stone, D., George, I. J., Mertes, S., van Pinxteren, D., Tilgner, A., Herrmann, H., Evans, M. J., and Heard, D. E.: The influence of clouds on radical concentrations: observations and modelling studies of HOx during the Hill Cap Cloud Thuringia (HCCT) campaign in 2010, Atmos Chem Phys, 15, 3289-3301, 10.5194/acp-15-3289-2015, 2015. 